\title{
The Farmers' Understanding of Rice Plant Culture on Local Variety (An Ethnographic Study for Farmers in Rice Fields Anjir Serapat)
}

\author{
Saiffullah Darlan $^{1^{*}} \quad$ Ishomuddin $^{2} \quad$ Rahayu Hartini $^{3} \quad$ Rinikso Kartono $^{2}$ \\ 1.Doctoral Studies Program of Social and Political Sciences, University of Muhammadiyah Malang, Indonesia \\ 2.Faculty of Social and Political Sciences, University of Muhammadiyah Malang, Indonesia \\ 3.Faculty of Law, University of Muhammadiyah Malang, Indonesia
}

\begin{abstract}
This article examines the understanding of paddy farming communities in Anjir Serapat, Kapuas Timur District, Kapuas District, Central Kalimantan, which always planted rice fields with local varieties of rice because they did not want to grow high-yielding rice as programmed by the government. This study aims to examine how the understanding of paddy farming communities towards the culture of planting local varieties of rice. This study used a qualitative method, and it is done naturally. The research subjects were paddy farmers with data collection techniques through observation, interviews, and documentation. Furthermore, the observation is carried out diligently so that the data obtained is more accurate by discussing it with the rice farming community. Furthermore, the data obtained were analyzed according to qualitative research procedures starting from (1) condensation data, (2) data display, and (3) verifying conclusions. The results of the study found that the understanding of rice farmers to grow local varieties of rice was caused by traditional and cultural factors from generation to generation. Where farmers have become accustomed to eating rice from Pera local varieties of rice, besides that there are also myths that influence the mindset in rice farming communities, there is an understanding that is a tradition that is not eating if you have not eaten village rice (belum makan kalau belum makan nasi kampung).
\end{abstract}

Keywords: rice of local varieties, the culture of rice farmers, myths in society

DOI: $10.7176 /$ RHSS/9-16-02

Publication date: August $31^{\text {st }} 2019$

\section{Introduction}

Farmers work to get a decent and prosperous life. Therefore, farmers work tirelessly from morning to evening, hoping to get much rice so that they can provide for their families. Lifelike this also happens for the rice farming community in Anjir Serapat, they work very hard and resilient, but their lives are still in a reduced standard of living. His main work is only farming local varieties of rice in tidal rice fields.

Tidal land is swampland in the downstream, which is in the river flow system, which has tidal influences. Then, the land is formed from the sedimentation of river deposits (Dirgasari et al. 2019). Although tidal rice fields, farmers cannot rely solely on the tide but still depend on rainwater. Farmers cultivate their fields starting from choosing Paung (rice seed), Manaradak (seeding seed), Mamacak (separating the rice seedlings after sowing) until they are permanently replanted until the Mangatam stage (harvesting), which is done once a year.

During the crisis (crisis), many farmers experience difficulties in their lives so that the giant farmers sell their belongings to be used as money in the hope that the food needs can be overcome. In this condition, moneyed people are offered a service so that farmers are willing to sell their rice at low prices, and the buyers will take it during the harvest season. However, during the harvest season, the rice that has been sold is sometimes insufficient to be paid to buyers because sometimes the rice planted is damaged due to pests or other calamities. As a result, many rice farmers become inadequate because of debt due to the sale of rice before harvest time. Popkin argues that "Peasants are often forcibly blocked from the market for the same reasons: development of markets can help the peasant to demand more, or even to do without his patron" (Popkin 1979) Furthermore, some paddy farmers are temporarily waiting for the harvest season, especially for men they go looking for work in other areas to look for additional family finances.

The government launched various kinds of superior rice varieties that had been released to the farmers' community as an effort to help farmers to get a lot of paddy rice. Superior rice varieties are varieties that have been released by the government that has advantages in the potential yield and candidate varieties tested. (Kementerian Pertanian 2006).

Efforts to accommodate the desire in the choice of farmers to plant local varieties of rice and so that farmers do not abandon planting superior varieties of rice, the government launched two tidal rice varieties which were a cross between local rice and superior rice named Martapura and Margasari varieties, so that the use of rice was superior this increases in tidal land in Central Kalimantan. Research and Development Center for Sosektan (Badan Penelitian dan Pengembangan Pertanian Departemen Pertanian 2003). 
Although Anjir Serapat paddy farmers already knew of the existence of new superior rice varieties and also the farmers were recommended by the government to grow the superior varieties of rice, because this rice could accommodate the wishes of farmers. However, it turned out that this recommendation did not produce satisfactory results, because until now, rice farmers still grow local varieties of rice. This research also different from previous research conducted by another researcher, Akongo et al. (2016) regarding the behavior of farmers in facing challenges and climate adaptation in the production of rice growth.

The existence of the phenomena and behavior of farmers has made researchers interested in conducting studies through a study of the understanding of rice farming communities towards the culture of planting local varieties of rice.

\section{Literature Review}

\subsection{EconomicTheories of Farmers}

Every talk about farmers' economic problems is inseparable from what has always been the problem of the farmers themselves. Thus, many social scientists discuss this farmer problem connecting the "Rational Farmer" theory proposed by Samuel L. Popkin (1979), with the theory "Economic Morals Farmer "brought by James C. Scott (1994), but both of these experts criticized each other for the theory he put forward.

In the Moral Economy of Farmer's theory, Scott takes precedence (safety-first) and minimizes the risk factors that will occur. According to the theory, farmers fulfill the principle of equity and the spirit of cooperation. In the theory of Rational Farmer's theory proposed by Popkin, farmers make an action always to be based on rationality factors and consider the principles of effectiveness and efficiency. This is what underlies Popkin's antithesis and rejects the farmers' morale, economic theory proposed by Scott. Furthermore, Popkin (1979) asserted, "Peasants are willing to be innovative on their position is secure against loss and success can measurably improve their position." Furthermore, Popkin also has the belief that the farming community basically has openness and always accept the existence of a market system so that if they have the opportunity, farmers also want them to eliminate the patron system and they are also always ready to face the risks that occur to farmers. Furthermore, he also emphasized that "Suggests that" The benefits of poor patrons who prevent the market involvement by peasants in order to protect their control of the economy (1979).

Popkin disagreed if the facilities provided by the Government were redundant or not utilized or the facilities were commercialized to farmers so that eventually the consequences for those who benefited would be to get rich, while for the farmers the community would become more impoverished.

\subsection{Farmer's Cultural Theory.}

Cultural scientists provide a variety of theories and concepts of culture, both general and specific so that each expert varies in interpreting the cultural theory. The cultural theory of David Kaplan and Robert A. Manners he put anthropology into a comprehensive science in his discussion, because taking human culture in all times and places as a legitimate field. Not only that anthropology also explores problems that include kinship and social organization, politics, technology, economics, religion, language, art, and mythology (Kaplan \& Manners 2012).

Furthermore, culture is a comprehensive concept and is formed from the results of the interaction and communication of all ideas, beliefs, and behaviors in the lives of community groups. Jasper (2007) explained the meaning of culture as an understanding of the mental world and shared manifestations.

Because culture is a social system of human behavior that gives birth to diversity and has an influence on traditional heritage, Spradley (2007) ... the culture of knowledge acquired, is used by people to interpret experiences and give birth to social behavior.

Trompenaars (1993), theorizing culture, is "culture come in layers, like an onion." There is a culture that can be seen in plain view and can always be observed directly on the outside, such as the behavior of procedures for the habits of everyday life, or the behavior of farmers in processing their fields.

However, the culture in the middle layer is the norms, values and noble traditions that exist in society, such as the norms of society in the case of someone communicating or talking to someone older than him, he must be able to choose which words he speaks in those conversations it says exactly right or what it says is wrong.

In the deepest part of the most core layer of culture is the belief that someone who believes that there is truth, for example in a farming community Anjir Serapat where farmers believe that when planting rice people must always pay attention to the position of the quarantine (five-star star or stingray stars) and Mix bar (threestar star). Seeing heavenly objects, farmers know when it is time for them to start and when to end planting rice, because if they neglect a belief they believe in, then what they do is in vain because their rice plants are attacked by Rat pests or Frogs. These methods strive for wealth ... and perhaps also an improvement in fate. ... (Weber 2009).

The fact that they are in the farming community has material and non-material culture; they hold fast from the two cultures and are practiced from generation to generation. Because the cultural meaning of the farming community is very difficult to separate between cultures as a pattern for life of farmers and culture as a pattern of 
life for farmers, the two patterns are then combined into 1 (one) unit that is not can be separated, this is because both are a series where he can form a way of life, about how farming communities can maintain, shape and can develop patterns of life as a cultural reality that exists in farming communities.

\section{Method}

By the characteristics of the Anjir Serapat community who farm in tidal rice fields, this study was carried out with qualitative methods, with an approach to an ethnographic study. The qualitative method can be used to uncover and understand something behind a phenomenon that is not yet known. Strauss and Corbin (2017). Ethnography is the work of describing a culture. The main purpose of this activity is to understand the view of life from the perspective of indigenous people ... (Spradley 2007). Ethnography is widely interpreted as a record, writing about ethnic groups. Ratna (2016). As key informants are rice farmers and data collection techniques for observation, interviews, and documentation. Data analysis was conducted referring to the qualitative research procedures presented by starting (1) condensation data (data condensation), (2) data display (data display), and (3), describe and verify conclusions (drawing and verifying conclusions).

\section{Result and Discussion}

The understanding of paddy farmer communities towards the culture of planting local varieties of rice, about the culture and traditions of the rice farming farmers of Anjir Serapat, is an inheritance from the previous Tutuha (ancestors) that they always followed from generation to generation. The understanding of the farming community towards the culture of planting local varieties of rice is more because, in the community itself, there is a myth of "not eating if you have not eaten village rice."

This myth greatly influences the understanding of mindset and behavior so that rice farmers consider local varieties of rice to be favorite rice for rice farming farmers in Anjir Serapat. The paddy farmer community is very proud of the rice fields are planted with local rice, although they know that the local varieties of rice are not as much as if they grow high-yield rice. Humaeni (2012) state that both traditional society (preliterate society) and modern society, always use myths that have sacred values for their adherents.

This understanding also makes the rice farming community very happy and plant as much as possible local varieties of rice, because if they grow much rice, of course, they will get many results so that the level (dignity) and dignity (self-esteem) of farmers in society becomes high, and if there are advantages after they consume, they can sell the rice. According to Scott (1994) explains that in large paddy fields, there is no problem with priorities for planting for subsistence, although planting "rice for sale" is far more profitable. The villagers only take care of the fields planted with "rice for sale."

Thus, it also made rice traders or rice traders at Anjir Serapat not want to sell rice or high-yielding rice because the rice or rice they sold was not selling well, which was due to the myths stated above, so this factor made local varieties of rice the price more expensive than selling superior varieties of rice.

\section{Conclusion}

The understanding of the farmers of Anjir rice fields Serapat to the culture of planting local varieties of rice is a cultural heritage of Tutuha (ancestors) which is always obeyed for generations. The understanding of the farming community is more due to the myth that has taken root in the lives of the people "we have not eaten if they have not eaten village rice."

The existence of a myth like this dramatically influences the mind, behavior, and culture so that the rice farming community. It makes the pattern of planting and considers local varieties of rice as rice to be proud, has a high degree, and dignity even though farmers know that this local rice variety the result is not as much as compared to planting superior varieties of rice.

\section{References}

Akongo, G. O., Gombya-Ssembajjwe, W., Buyinza, M., \& Bua, A. (2016), "Farm-Level Adaptive Capacity to Climate Variability In Rice Production, Northern Uganda”, Research on Humanities and Social Sciences, 6 (14), IISTE, 27-36. Retrieved from https://iiste.org/Journals/index.php/RHSS/article/view/32081

Badan Penelitian dan Pengembangan Pertanian Departemen Pertanian. (2003), "Prosiding seminar hasil-hasil penelitian dan pengkajian teknologi pertanian di lahan pasang surut”, Palangka Raya: Puslitbang Sosektan.

Dirgasari, K. D., Hasmeda, M., \& Harun , U. (2019), "Testing of Some Rice Varieties (Oryza Sativa L.) on FE2+ Stressing Condition at Tidal Land”, AGROSAINSTEK: Jurnal Ilmu dan Teknologi Pertanian, 3 (1), 30-35. doi:10.33019/agrosainstek.v3i1.55.

Humaeni, A. (2012), "Makna Kultural Mitos Dalam Budaya Masyarakat Banten”, Antropologi Indonesia, 33(3). Retrieved 12 1, 2018, from http://journal.ui.ac.id/index.php/jai/article/viewArticle/2461

Jasper, J. M. (2007), "Cultural Approaches in the Sociology Of Social Movements", (B. Klandermans and C. Roggeband, Eds), In J. M. Jasper, Handbook of Social Movements across Disciplines (pp. 59-109), New 
York, NY: Springer.

Kaplan, D., \& Manners , R. (2012), “Teori Budaya” (Landung Simatupang, Trans), Yogyakarta: Pustaka Pelajar. Kementerian Pertanian. (2006), "Peraturan Menteri Pertanian No. 37/Permentan/OT.140/8/2006", Tentang Pengujian, Penilaian, Pelepasan dan Penarikan Varietas, Jakarta: Setjen. Kementan.

Miles, B., Huberman, A., \& Aldana, J. (2014), "Qualitative Data Analysis. A Method Sourcebook (3rd Ed.)", London: SAGE Publication, Inc.

Moerman, M. (1968), “Agricultural Change and Peasant Choice in A Thai Village,” Berkeley and Los Angeles: University of California.

Popkin, L. S. (1979), "The Rational Peasant: The Political Economy of Rural Society in Vietnam, Berkeley: University of California Press.

Ratna, N. (2016), "Metodologi Penelitian. Kajian Budaya dan Ilmu Sosial Humaniora Pada Umumnya", Denpasar: Pustaka Pelajar.

Scott, J. C. (1994), "Moral Ekonomi Petani, Pergolakan dan Subsistensi di Asia Tenggara (Hasan Basari, Trans)", Jakarta: LP3ES.

Spradley, J. P. (2007), "Metode Etnografi (2nd Ed.), (M. Yahya, Ed., \& M. Z. Elizabeth, Trans.)”, Sleman, Yogyakarta: Tiara Wacana.

Strauss, A., \& Corbin, J. (2017), "Dasar-Dasar Penelitian Kualitatif. Tata Langkah dan Teknik-Teknik Teoritisasi Data (5th Ed.), Yogyakarta: Pustaka Pelajar.

Trompenaars, F. (1993), "Riding The Waves Of Culture: Understanding Cultural Diversity in Business (2nd Ed.)", London: Nicholas Brealey Publishing.

Weber, M. (2009), "Sosiologi. (Noorkholis, Trans.)", Yogyakarta: Pustaka Pelajar Offset. 